\title{
Anti-oxidant and anti-arthritic potential of Ayurvedic formulations: Maharasnadi quath extract and Stifain tablet
}

\author{
Nimish Vador ${ }^{1 *}$, Bhavesh Vador $^{2}$, Nirali Rajgor ${ }^{3}$ \\ ${ }^{1,2}$ Dept. of Medical, ${ }^{3}$ Dept. of Research and Development, Ayurchem Products, Dombivali, Maharashtra, India
}

*Corresponding Author: Nimish Vador

Email: nimishvador@gmail.com

\begin{abstract}
Traditional system of medicines has been in use since ages throughout the world. Ayurvedic granthokt extracts have been in use to treat many disorders which are either non-communicable or lifestyle oriented or due to stress. Rheumatoid arthritis is one of the autoimmune disorder which might arise due to faulty metabolism of body or stress. It is a chronic inflammatory disorder which results in severe pain, discomfort and sometimes disability in the patients. Modern medicines aims to reduce pain but the root cause remains unattended. Hence the main objective was to assess the in vitro Antioxidant and Anti-inflammatory activity of the Ayurvedic formulation Maharasnadi kwath extract and Stifain tablet. The Antioxidant properties of the Maharasnadi kwath and Stifain tablet were evaluated by 2, 2-diphenyl-1-picrylhydrazyl (DPPH) free radical scavenging assay. Anti-inflammatory activity was estimated by inhibition of protein denaturation method. The aqueous extract of Maharasnadi and Stifain tablet showed good anti-inflammatory activities and potent antioxidant capacity.
\end{abstract}

Keywords: Antioxidant, Anti-inflammatory activity, Albumin denaturation, Maharasnadi kwath, Stifain tablet, Nervous system.

\section{Introduction}

Inflammation in any part of the body results either due to physical injury or due to internal faulty metabolism of the body. Faulty metabolism of the body may originate from improper diet, irregular food timings, anger, stress. As per Ayurveda, faulty metabolism of body produces Aam (toxins or Reactive Oxygen Species). These Aam or Reactive Oxygen Speices (ROS) are highly unstable compounds and are key signaling molecules that play an important role in the progression of inflammatory disorders. As per Ayurveda ROS leads to imbalance in the three main pillars of the body that is vata-pitta-kapha. Under normal conditions, ROS levels are controlled by the body's complex antioxidant defense system and there is an equilibrium between ROS formation and degradation. Overproduction of ROS and/or inadequate antioxidant defense disturbs this equilibrium in favor of a ROS upsurge that results in oxidative stress. A deficiency in the body's natural antioxidant defense mechanisms has been implicated as the etiological or pathological factor in several clinical disorders. ${ }^{1}$

Various research studies have indicated the role of ROS in Rheumatoid Arthritis. ROS affects the micro-circulation of blood vessels near the site of inflammation. The microcirculation is the main playground where the process of inflammatory cascade was evaluated and analyzed. ${ }^{1}$ Inflammation includes a long chain of molecular reactions and cellular activity, which are designed to restore a tissue from simple skin cut or to cure several burn injuries in inflammatory process, it is important to understand the role of chemical mediators. These mediators come from plasma proteins or cells including mast cells, platelets, neutrophils and monocytes. They are triggered by bacterial products or host proteins. Chemical mediators bind to specific receptors vascular permeability, neutrophil, chemotaxins, stimulate smooth muscle contraction, have direct enzymatic activity, induce pain or protein denaturation and mediate oxidative damage, causing the protein to lose its molecular conformation and functions or become denatured. ${ }^{2-5}$ It is therefore deduced that, compounds which are able to prevent these changes and inhibit thermally or heat induced protein denaturation, have potential therapeutic value as antiinflammatory agents. ${ }^{4}$

The World Health Organization (WHO) has estimated that $80 \%$ of the world inhabitants utilized traditional medicine for their primary health care needs and the majority of this therapy requires the use of herbal extracts and their active components. Various medicinal plant bioactive extracts and their identified/isolated active constituents have shown a variety of medicinal pharmacological properties against various acute and chronic diseases/disorders. ${ }^{6-8}$ Currently, the impact of oxidative stress and its associated factors has become an important issue of human health. ${ }^{9}$ When the body is under a lot of stress, results in protein denaturation and the production of ROS (e.g., hydroxyl radicals, superoxide anion radicals, and hydrogen peroxide) is amplified. ${ }^{10}$ Endogenous enzymatic and non-enzymatic antioxidant substance are not able to handle the overload of ROS and lead to imbalances of the process, cell damage, ${ }^{11}$ and health problems. ${ }^{12}$

Table 1: Composition of Stifain tablet (Each film coated tablet contains)

\begin{tabular}{|l|c|c|c|}
\hline S.No. & Ingredient Name. & Part used & Quantity \\
\hline 1. & Maharasnadi kvatha $^{13}$ & Extract & $150 \mathrm{mg}$ \\
\hline 2. & Yograj guggul $^{14}$ & Powder & $100 \mathrm{mg}$ \\
\hline 3. & Mahavatvidhwans ras $^{15}$ & Powder & $50 \mathrm{mg}$ \\
\hline
\end{tabular}




\begin{tabular}{|l|c|c|c|}
\hline 4. & Ekangvir ras $^{16}$ & Powder & $50 \mathrm{mg}$ \\
\hline 5. & Sameer pannag ras $^{17}$ & Powder & $25 \mathrm{mg}$ \\
\hline & Processed with (Bhavna Dravya) & & QS \\
\hline 6. & Brahmi(Bacopa monneri) $)^{18}$ & Whole plant & QS \\
\hline 7. & Eranda (Ricinus communis) ${ }^{19}$ & Root & QS \\
\hline 8. & Guduchi (Tinospora cordifolia) $^{20}$ & Stem & QS \\
\hline 9. & Shatavari (Asparagus racemosus) $^{21}$ & Root & QS \\
\hline 10. & Parsika yavni (Hyoscymus niger) $)^{22}$ & Seed & \\
\hline
\end{tabular}

Fine powder of all these medicinal ingredients is combined together in Mixer along with other approved Tablet excipients. Granules are prepared from the earlier process is punched in to tablets. Tablets obtained are coated with moisture barrier coat and later with FDA approved color coat to identify the product.

Table 2: The Polyherbal Formulation of Maharasnadi kwath ${ }^{23}$

\begin{tabular}{|l|c|c|c|c|}
\hline S.No. & Name of Ingredients & Botnical name & Part used & Proportion \\
\hline 1 & Rasna & Pluchea lanceolata & Whole & 2 parts \\
\hline 2 & Eranda & Ricinus communisLinn. & Root & 1 part \\
\hline 3 & Devadaru & Cedrus deodar Roxb. & Heart wood & 1 part \\
\hline 4 & Shati & Hadychium spicatum & Root & 1 part \\
\hline 5 & Vacha & Acorus calamus & Root & 1 part \\
\hline 6 & Vasa & Adhatoda vesica & Fruit & 1 part \\
\hline 7 & Sunth & Zingiber officinalis & Root & 1 part \\
\hline 8 & Harda & Terminali achebula & Fruit & 1 part \\
\hline 9 & Bala & Sida cordifolia & Root & 1 part \\
\hline 10 & Chavya & Piper chaba & Root & 1 part \\
\hline 11 & Musta & Cyperus rotundus & Stem & 1 part \\
\hline 12 & Punarnava & Boerhavia diffusaLinn & Stem & 1 part \\
\hline 13 & Guduchi & Tinospora cordifolia & fruit & 1 part \\
\hline 14 & Vriddhdaru & Argyreia speciosa & Fruit & 1 part \\
\hline 15 & Shatpushpa & Anethum sowa & Root & 1 part \\
\hline 16 & Gokshura & Tribulus terrestris & Root & 1 part \\
\hline 17 & Aswaghandha & Withania somnifera & Root & 1 part \\
\hline 18 & Shatavari & Asparagus recemosus & Stem bark & 1 part \\
\hline 19 & Ativisha & Aconitum heterophyllum & Fruit & 1 part \\
\hline 20 & Garmala & Cassia fistula & Whole plant & 1 part \\
\hline 21 & Pippali & Piper longum & Fruit & 1 part \\
\hline 22 & Sahachara & Barleria prionitis & Whole plant & 1 part \\
\hline 23 & Dhanyaka & Coriandrum sativum & Whole plant & 1 part \\
\hline 24 & Brihati & Solanum indicum & Whole plant & 1 part \\
\hline 25 & Kantakari & Solanum surratance & & \\
\hline 26 & Dhamasa & Fagonia arabica & & \\
\hline
\end{tabular}

\section{Materials and Methods}

Chemicals - 2,2-diphenyl-1-picrylhydrazyl Powder (DPPH), Bovine serum albumin Fraction- V(BSA) and Aspirin powder from Hi Media. Solvent Methanol (analytical grade) obtained from Merck.

\section{Antioxidant activity using determination of DPPH free radical scavenging activity: ${ }^{25}$}

This free radical scavenging Capacity of aqueous Extract of Maharasnadi and Stifain tablet was determined using based on 2, 2-diphenyl-1-picrylhydrazyl.the ability of the antioxidants present in the Maharasnadikwath and Stifaintablet polyherbal formulation to decolorize the DPPH radical. DPPH radicals absorbed maximum at $514 \mathrm{~nm}$, which disappears with reduction by an antioxidant compound.

About $0.5 \mathrm{gm}$ of Maharasnadi kwath and Stifain tablet Powder was measured using an Analytical balance (Citizen CY 220) and was added to $5 \mathrm{ml}$ of distilled water separately. The solution was mixed well using a vortex. Boil on water bath for $10 \mathrm{~min}$. Serial dilution from 100 to $1000 \mu \mathrm{g} / \mathrm{ml}$ was performed using methanol for Maharasnadi kwath and Stifain tablet.

\section{Test solution $(3 \mathrm{ml})$}

$2.5 \mathrm{ml}$ DPPH solution in methanol $(100 \mu \mathrm{M})$ was mixed with $0.5 \mathrm{ml}$ of different Concentration of extracts $(\mathrm{mcg} \backslash \mathrm{ml})$. 


\section{Control solution ( $3 \mathrm{ml})$}

$2.5 \mathrm{ml} \mathrm{DPPH}$ solution in methanol $(100 \mu \mathrm{M})$ was mixed with $0.5 \mathrm{ml}$ of methanol (without extract).

Test solution $(0.5 \mathrm{ml})$ of different concentrations (100 to $1000 \mathrm{mcg} / \mathrm{ml}$ ) and Control solution were mixed with $2.5 \mathrm{ml}$ DPPH solution $(100 \mu \mathrm{M})$. Then the samples were incubated at Room temperature in dark for 20min.Absorbance of reaction mixture was measured for each concentration at 514 $\mathrm{nm}$ using UV-Visible spectrophotometer (Shimadzu UV1800) Each test was repeated thrice and the mean absorbance was recorded. The percentage of inhibition of Radical scavenging activity was determined on a percentage basis with respect to control using the following formula:

\section{Inhibition of DPPH (\%) = (AC - AT/ AC $) \times 100$}

Where,

AC - Absorbance of control solution

AT - Absorbance of Test solution.

Anti-inflammatory activity using Bovine serum albumin (BSA) denaturation method: ${ }^{26}$

About $0.2 \mathrm{gm}$ of Aspirin, Maharasnadi kwath and Stifain tablet Powder was measured using an Analytical balance (Citizen CY 220) and was added to $20 \mathrm{ml}$ of distilled water separately. The solution was mixed well using a vortex.

Serial dilution from $1000 \mu \mathrm{g} / \mathrm{ml}$ to $0.01 \mu \mathrm{g} / \mathrm{ml}$ was performed for Maharasnadi kwath, Stifain tablet and for reference Drug (Aspirin).

\section{Test solution $(0.5 \mathrm{ml})$}

$0.45 \mathrm{ml}$ aqueous solution of BSA $0.5 \% \mathrm{w} / \mathrm{v}$ and $0.05 \mathrm{ml}$ Test solution of different concentrations were used.

\section{Test control solution $(0.5 \mathrm{ml})$}

$0.45 \mathrm{ml}$ aqueous solution of BSA $0.5 \% \mathrm{w} / \mathrm{v}$ and $0.05 \mathrm{ml}$ Distilled water were used.

\section{Product control $(0.5 \mathrm{ml})$}

$0.45 \mathrm{ml}$ Distilled water and $0.05 \mathrm{ml}$ Test solution of different concentrations were used.

\section{Standard solution $(0.5 \mathrm{ml})$}

$0.45 \mathrm{ml}$ aqueous solution of BSA $0.5 \% \mathrm{w} / \mathrm{v}$ and $0.05 \mathrm{ml}$ Aspirin of different concentrations were used.

Test solution $(0.05 \mathrm{ml})$ of different concentrations from 0.01 microgram per $\mathrm{ml}-1000$ microgram per $\mathrm{ml}$ and standard drug Aspirin $(0.05 \mathrm{ml})$ of different concentrations $0.01,0.1,1,10,100,1000 \mu \mathrm{g} / \mathrm{ml}$ ) were mixed with $0.5 \% \mathrm{w} / \mathrm{v}$ aqueous solution of BSA $(0.45 \mathrm{ml})$. Then the samples were incubated at $37^{\circ} \mathrm{C}$ for $20 \mathrm{~min}$ followed by incubation at $57^{\circ} \mathrm{C}$ for $3 \mathrm{~min}$. $2.5 \mathrm{ml}$ of phosphate buffer (pH 6.4) was added to all the above samples after cooling. Absorbance of reaction mixture was measured for each concentration at $255 \mathrm{~nm}$ using UV-Visible spectrophotometer (Shimadzu UV-1800) each test was repeated thrice and the mean absorbance was recorded. The percentage of inhibition of protein was determined on a percentage basis with respect to control using the following formula:
Percentage inhibition $(\%)=100-[($ ATS - APC $) /$ ATC $]$ x100

whereas:

ATS - absorbance of the test solution

APC - absorbance of the Product control

ATC - absorbance of the test control solution

\section{Statistical analysis}

All data were analyzed statistically using UV spectrophotometer (Shimadzu UV-1800). The descriptive data were expressed as mean \pm standard error of mean. Linear regression analysis was performed to find out correlation coefficient. The percentage of inhibition rate between different groups were analyzed by independent sample t-test.

\section{Results}

\section{Antioxidant activity using DPPH}

Free radical scavenging potential (DPPH) of the polyherbal Formulation Maharasnadi kwath extracts and Stifain tablet at different concentrations is represented below. The free radical scavenging activity increases with increase in the concentration of the sample which was reflected at the decrease in the absorbance. The ability of Maharasnadi kwath extract and Stifain tablet to scavenge DPPH free radical was calculated as percentage inhibition which was $94.609 \%$ and $92.602 \%$ and respectively at concentration of $1000 \mu \mathrm{g} / \mathrm{ml}$. TheIC50 value of Maharasnadi kwath and Stifain tablet was found to be $395 \mu \mathrm{g} / \mathrm{ml}$ and $426 \mu \mathrm{g} / \mathrm{ml}$ Respectively. (Fig. 1,2)

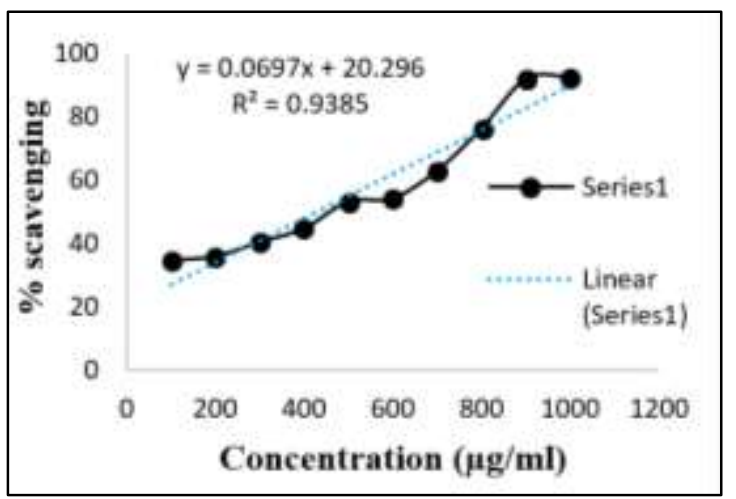

Fig. 1: Scavenging effect (\%) on DPPH by Maharasnadi Kwath at different concentration

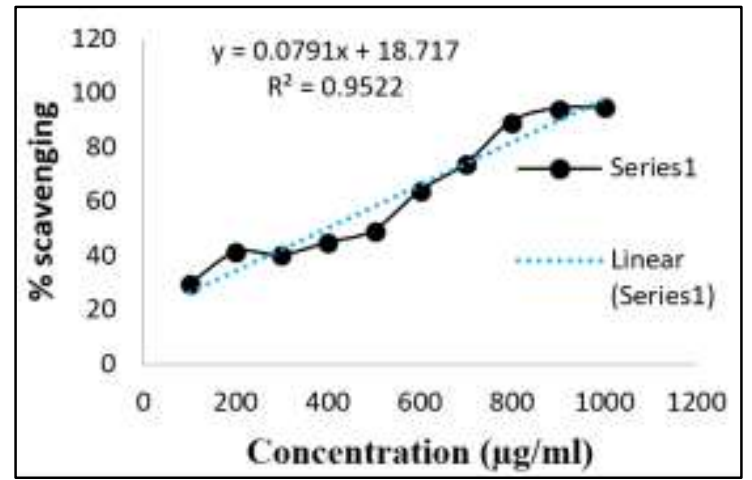

Fig. 2: Scavenging effect (\%) on DPPH by Stifain tablet at different concentration 


\section{Anti-inflammatory Activity using bovine serum denaturation}

Anti-inflammatory activity of Maharasnadi kwath extract and Stifain tablet was evaluated against BSA denaturation method. The highest inhibition rate was observed at the concentration of $1000 \mu \mathrm{g} / \mathrm{ml}$ shown $10.53 \%$ and $14.72 \%$ protected Bovine serum albumin (BSA) against heat denaturation at concentrations (Table 3 ).

This result compared with the reference drug Aspirin, it showed the maximum inhibition $17.43 \%$ at the concentration of $1000 \mu \mathrm{g} / \mathrm{ml}$. (Table 4 ).

The value of IC 50 of aqueous extract of Maharasnadi kwath and Stifain tablet was $19,758 \mu \mathrm{g} / \mathrm{ml}, 11,079 \mu \mathrm{g} / \mathrm{ml}$, respectively. (Table 3) In addition, the value of IC 50of Aspirin was $8877 \mu \mathrm{g} / \mathrm{ml}$. (Table 4).

Table 3: The percentage of inhibition rate of protein denaturation of Maharasnadi kwath and Stifain table.

\begin{tabular}{|l|c|c|}
\hline \multirow{2}{*}{$\begin{array}{l}\text { Concentration } \\
(\boldsymbol{\mu} \mathbf{g} / \mathbf{m l})\end{array}$} & \multicolumn{2}{|c|}{ Rate of inhibition (\%) } \\
\cline { 2 - 3 } 0.01 & Maharasnadi kwath & Stifain tablet \\
\hline 0.1 & $6.35 \pm 0.01$ & $9.44 \pm 3.16$ \\
\hline 1 & $8.01 \pm 0.40$ & $10.57 \pm 0.01$ \\
\hline 10 & $9.35 \pm 0.46$ & $10.95 \pm 0.81$ \\
\hline 100 & $9.53 \pm 0.18$ & $12.84 \pm 0.01$ \\
\hline 1000 & $9.63 \pm 0.01$ & $12.86 \pm 0.02$ \\
\hline IC 50 & $10.53 \pm 0.20$ & $14.72 \pm 1.36$ \\
\hline
\end{tabular}

Results are shown as mean \pm SEM. SEM: Standard error of the mean

Table 4: The percentage of inhibition rate of protein denaturation of reference drug Aspirin.

\begin{tabular}{|l|c|}
\hline Concentration $(\boldsymbol{\mu g} / \mathbf{m l})$ & $\begin{array}{c}\text { Rate of inhibition(\%) of } \\
\text { Aspirin }\end{array}$ \\
\hline 0.01 & $12.02 \pm 2.80$ \\
\hline 0.1 & $12.19 \pm 3.00$ \\
\hline 1 & $12.50 \pm 0.01$ \\
\hline 10 & $15.70 \pm 1.71$ \\
\hline 100 & $16.30 \pm 0.93$ \\
\hline 1000 & $17.43 \pm 0.02$ \\
\hline IC 50 & $\mathbf{8 8 7 7} \boldsymbol{\mu g} / \mathbf{m l}$ \\
\hline
\end{tabular}

Results are shown as mean \pm SEM. SEM: Standard error of the mean.

\section{Discussion}

Standardized aqueous extract of Maharasnadi quath extract was used to study the anti-oxidant and anti-arthritic property. The extract was standardized to total Phenolics content NLT $5 \%$. The role of Maharasnadi quath extract is mostly observable on the nervous system and musculoskeletal system. Maharasnadi kwath pacifies inflammation and irritation of nerves and removes toxins from the body. Furthermore, it reduces inflammation of organs/parts of the musculoskeletal system. Therefore, it is recommended for paralytic disorders and arthritis. It has antitoxin and AMA Pachak (Detoxifier) actions, which reduces Aam formation, removes aamvisha from the channels and facilitates their quick elimination from the body. Therefore, it helps in diseases in which Aam or aamvisha are responsible or play as an underlying cause of the disease e.g. Rheumatoid Arthritis.

Stifain tablet is the multiherbal combination of Maharasnadi quath extract, Mahavatvidhwans Ras, Ekangveer ras, Yograj guggul processed with Ashwagandha, Shatavari, and other herbs. This tablet combination increases digestion power and opens up all the (shrotas) channels for proper blood circulation towards the site of inflammation. It might also reduce the nerve inflammation there by reducing the pain in rheumatoid arthritis. It possess good antioxidant property which further enhances the activity of the Stifain tablet.

\section{Conclusion}

Standardized extract of Maharasnadi quath extract and Stifain tablets showed very good anti-oxidant and antiarthritic activity. Stifain tablets may be used as a single drug therapy for arthritis.

\section{Source of Funding \\ None.}

\section{Conflict of Interest}

None.

\section{References}

1. Schmid-Schonbein GW. Analysis of inflammation. Annu Rev Biomed Eng. 2006;8:93-151.

2. Kandikattu K, Bharath RKP, Venu PR, Sunil KK, Singh R. Evaluation of anti-inflammatory activity of Canthium parviflorum by in-vitro method. Indian J Res Pharm Biotech. 2013;1(5):729-30.

3. Dharsana JN, Mathew SM. Preliminary screening of antiinflammatory and antioxidant activity of Morinda umbellata. Int J Pharm Life Sci. 2014;5(8):3774-79.

4. Anyasor GN, Funmilayo O, Odutola O, Olugbenga A, Oboutor EM. Evaluation of Costus afer Ker Gawl. In vitro antiinflammatory activity and its chemical constituents identified using gas chromatography-mass spectrometry analysis. $J$ Coastal Life Med. 2015;3(2):132-8.

5. Sridevi G, Sembulingam K, Muhammed I, Srividya S, Prema S. Evaluation of in- vitro anti-inflammatory activity of Pergularia daemia. World J Pharm Res. 2015;4(6):1100-8.

6. Chatterjee P, Chandra S, Dev P, Bhattacharya S. Evaluation of anti-inflammatory effects of green tea and black tea: A comparative in vitro study. J Adv Pharm Technol Res. 2012;3(2):136-8.

7. Tatti PN, Anitha S, Shashidhara S, Deepak M, Bidari S. Evaluation of in-vitro anti-denaturation activity of isolated compound of Butea monosperma Bark. Pharma Sci Monit. 2012;3(4):2314-20.

8. Dar SA, Yousuf AR, Ganai FA, Sharma P, Kumar N, Singh R. Bioassay guided isolation and identification of antiinflammatory and anti-microbial compounds from Urta dioica L. (Urticaceae) leaves. Afr J Biotechnol. 2012;11(65):1291020.

9. Krishnaiah D, Sarbatly R, Nithyanandam R. A review of the antioxidant potential of medicinal plant species. Food Bioprod Processing. 2011;89(3):217-33. 
10. Gerber M, Ruault MC, Hercberg S, Riboli E, Scalbert A, Siess MH. Food and cancer: state of the art about the protective effect of fruits and vegetables. Bull du Cancer. 2002;89(3):293-312.

11. Bhatia S, Shukla R, Madhu SV, Gambhir JK, Prabhu KM. Antioxidant status, lipid peroxidation and nitricoxide end products in patients of type 2 diabetes mellitus with nephropathy. Clin Biochem. 2003;36(7):557-62.

12. Steer P, Millgard J, Sarabi DM. Cardiac and vascular structure and function are related to lipid peroxidation and metabolism. Lipids, 2002;37(3):231-6.

13. Sahatrayog (Sanskrit-Hindi translation), Panditrao DV (Anusandhan adhikari) (Ayu.), Nair D. Kendiriya Ayurved Eva Sidhha Anusandhan Parishad Publication: 80-1.

14. Rastantrasar, Published by Krishna Gopal Ayurved Bhavan, Ajmer; 1980;1:642.

15. Rastantrasar, Published by Krishna Gopal Ayurved Bhavan, Ajmer; 1980;1:459.

16. Rastantrasar, Published by Krishna Gopal Ayurved Bhavan, Ajmer; 1980;1:470.

17. Bhavprakash Nighantu - Shri bhavmishra commentary by Chunekar KC edited by Panday GS, Chaukhambha Bharthi Academy Publishers and Distributors of Monumental Treatises of the east. Varanasi. Republished 2004:461.

18. Bhavprakash Nighantu - Shri bhavmishra commentary by Chunekar KC edited by Panday GS, Chaukhambha Bharthi Academy Publishers and Distributors of Monumental Treatises of the east. Varanasi. Republished 2004:299.

19. Bhavprakash Nighantu - Shri bhavmishra commentary by Chunekar KC edited by Panday GS, Chaukhambha Bharthi
Academy Publishers and Distributors of Monumental Treatises of the east. Varanasi. Republished 2004:270.

20. Bhavprakash Nighantu - Shri bhavmishra commentary by Chunekar KC edited by Panday GS, Chaukhambha Bharthi Academy Publishers and Distributors of Monumental Treatises of the east. Varanasi. Republished 2004:392.

21. Bhavprakash Nighantu - Shri bhavmishra commentary Chunekar KC edited by Panday GS, Chaukhambha Bharthi Academy Publishers and Distributors of Monumental Treatises of the east. Varanasi. Republished 2004:25.

22. Rasyogsar, Vaidya pandit hariprapannaji, Krishnadas academy Varanasi, Vol.2:489.

23. Shadgdharsahita 1971:226-7.

24. Dar MA, Mubashir H. Masoodi, Kour P, Shapoo NS. In vitro antioxidant activity of methanol aerial extract of mentha arvensis linn from Kashmiri Himalaya. Am J Pharma Tech. 2004;4:251-61.

25. Rahman H, Eswaraiah MC, Dutta AM. In-vitro antiinflammatory and anti-arthritic activity of Oryza sativa var. joha rice (an aromatic indigenous rice of Assam). Am-Eurasian J Agric Environ Sci. 2015;15:115-21.

How to cite this article: Vador N, Vador B, Rajgor N. Antioxidant and anti-arthritic potential of Ayurvedic formulations: Maharasnadi quath extract and Stifain tablet. Indian J Pharm Pharmacol 2020;7(1):43-7. 